\title{
Fulminant cerebral demyelination in neuromyelitis optica
}

\section{Figure $1 \quad$ MRI at diagnosis of neuromyelitis optica 5 months prior to herniation}
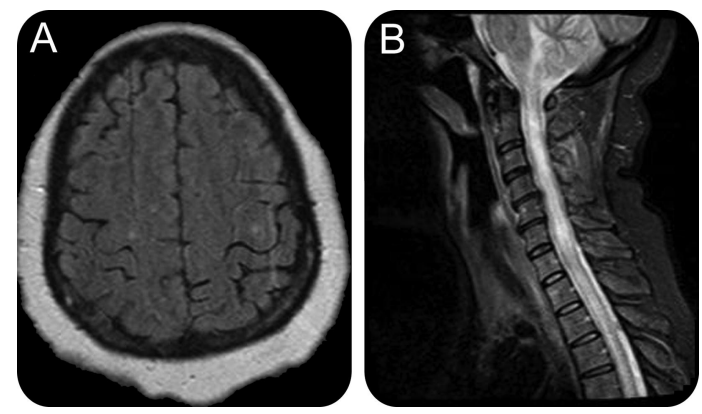

(A) Axial fluid-attenuated inversion recovery image shows nonspecific T2 hyperintensities. (B) Cervical sagittal short T1 inversion recovery shows longitudinally extensive myelitis extending into the thoracic cord.
Figure 2 Imaging of fulminant cerebral edema and demyelination
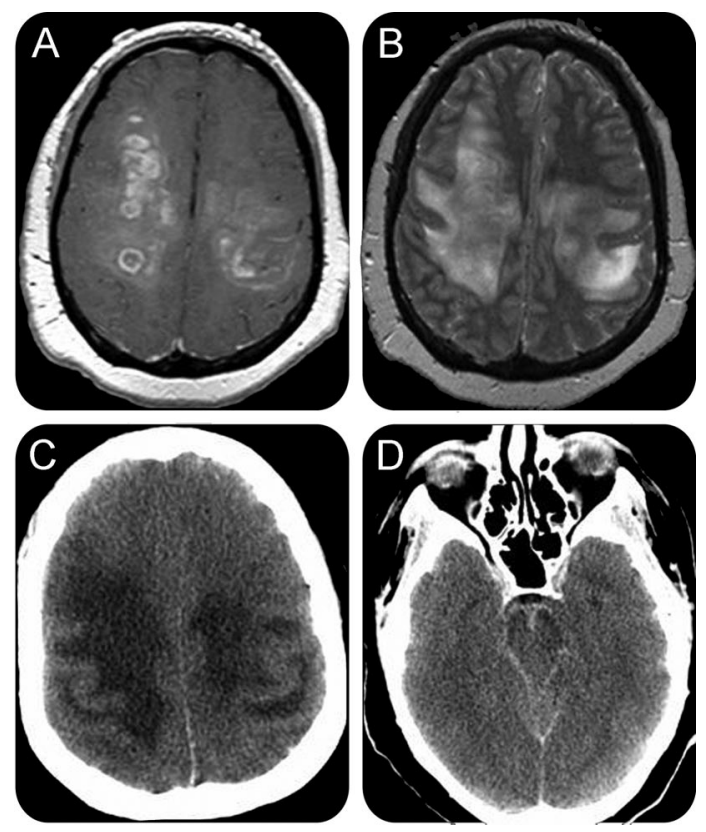

(A) Axial T1-weighted postcontrast image shows multiple ring-enhancing demyelinating lesions bilaterally. (B) Axial T2-weighted image shows extensive vasogenic edema. (C) Diffuse vasogenic edema on head CT (C) with loss of ambient cisterns and uncal herniation (D).

A 43-year-old woman with a 2-year history of neuromyelitis optica (NMO; typical imaging [figure 1] and NMO-immunoglobulin G [IgG] antibody), previously treated with plasmapheresis and steroids, presented somnolent. Admission neuroimaging showed fulminant cerebral demyelination (figure 2, A and B), and she rapidly progressed to herniation (figure $2, \mathrm{C}$ and $\mathrm{D}$ ) and brain death despite 2 courses of plasma exchange, mannitol, hypertonic saline, and methylprednisolone.

NMO-IgG-positive demyelinating disease may include fulminant edematous cerebral demyelination. ${ }^{1}$ The mechanism may involve deficient clearance of vasogenic edema via the aquaporin- 4 water channel. ${ }^{2}$ Early evaluation of NMO-IgG in atypical demyelinating cases may permit early aggressive treatment with steroids, plasmapheresis, or chemo-immunosuppression.

Christopher R. Newey, DO, MS, Robert A. Bermel, MD, Cleveland, OH

Author contributions: Dr. Newey contributed equally to the writing of the case and formatting the images. Dr. Bermel contributed equally to the writing of the case and formatting the images.

Disclosure: Dr. Newey reports no disclosures. Dr. Bermel serves as a consultant and on the speakers' bureaus for Biogen Idec and Teva Pharmaceutical Industries Ltd. and receives research support from the National Multiple Sclerosis Society.

Address correspondence and reprint requests to Dr. Christopher R. Newey, Department of Neurology, Cleveland Clinic Foundation, 9500 Euclid Avenue, Cleveland, OH 44195; neweyc@ccf.org

1. Matsushita T, Isobe N, Matsuoka T, et al. Extensive vasogenic edema of anti-aquaporin-4 antibody-related brain lesions. Mult Scler 2009;15:1113-1117.

2. Magana SM, Matiello M, Pittock SJ, et al. Posterior reversible encephalopathy syndrome in neuromyelitis optica spectrum disorders. Neurology 2009;72:712-717. 


\title{
Neurology
}

\author{
Fulminant cerebral demyelination in neuromyelitis optica \\ Christopher R. Newey and Robert A. Bermel \\ Neurology 2011;77;193 \\ DOI 10.1212/WNL.0b013e3182242d6e
}

This information is current as of July 11, 2011

\section{Updated Information \& Services}

References

Subspecialty Collections

Permissions \& Licensing

Reprints including high resolution figures, can be found at: http://n.neurology.org/content/77/2/193.full

This article cites 2 articles, 1 of which you can access for free at: http://n.neurology.org/content/77/2/193.full\#ref-list-1

This article, along with others on similar topics, appears in the following collection(s):

All Demyelinating disease (CNS)

http://n.neurology.org/cgi/collection/all_demyelinating_disease_cns CT

http://n.neurology.org/cgi/collection/ct

Devic's syndrome

http://n.neurology.org/cgi/collection/devics_syndrome

MRI

http://n.neurology.org/cgi/collection/mri

Information about reproducing this article in parts (figures,tables) or in its entirety can be found online at:

http://www.neurology.org/about/about_the_journal\#permissions

Information about ordering reprints can be found online:

http://n.neurology.org/subscribers/advertise

Neurology ${ }^{\circledR}$ is the official journal of the American Academy of Neurology. Published continuously since 1951, it is now a weekly with 48 issues per year. Copyright Copyright (? 2011 by AAN Enterprises, Inc.. All rights reserved. Print ISSN: 0028-3878. Online ISSN: 1526-632X.

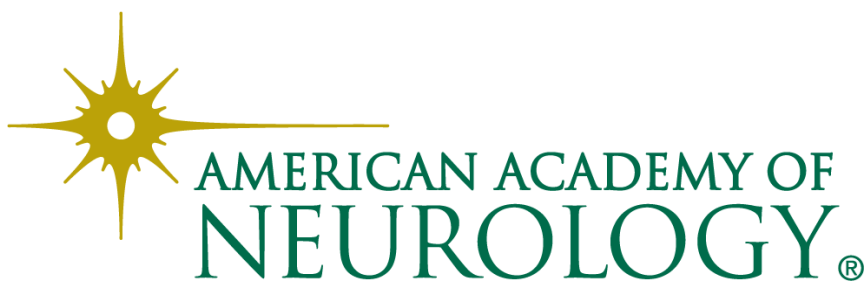

